\title{
Geoscięnces
}

\section{Ultrasound technique to assess the physical conditions of the Monument to Ramos de Azevedo, city of São Paulo, Brazil}

http://dx.doi.org/10.1590/0370-44672015680017

\author{
Danielle Grossi \\ Doutoranda em Ciências do Programa \\ Geociências (Mineralogia e Petrologia) - USP - \\ Universidade de São Paulo Paulo - Instituto de \\ Geociências \\ São Paulo, SP, Brazil \\ danigrossi@usp.br

\section{Eliane Aparecida Del Lama} \\ Professora Doutora, USP - Universidade de São \\ Paulo - Instituto de Geociências - Departamento \\ de Mineralogia e Geotectônica \\ São Paulo, SP, Brazil \\ edellama@usp.br
}

\section{Uso do equipamento de ultrassom para avaliação das condições físicas do Monumento a Ramos de Azevedo, São Paulo, Brasil}

\begin{abstract}
This paper presents the evaluation of the conservation of the Monument to Ramos de Azevedo through a study of the ultrasound pulse velocity. The Monument to Ramos de Azevedo is of great importance for the history of the city of São Paulo (Brazil), because it honors the architect who was fundamental in the architectural and social development of the city. This monument was built with Itaquera Granite, a stone widely used in the cultural heritage of the city, which is more specifically called biotite monzogranite. The equipment used was the V-Meter Mark III and only P waves were used with $54 \mathrm{kHz}$ transducers. Several measurements were taken on the monument and on fresh stone, and the results were compared. Results showed that the stone is in good condition even after changing locations twice because the values are very close to those of the fresh sample. The low values were attributed to internal discontinuities or biotite enclaves, the latter being very common in the Itaquera Granite.
\end{abstract}

Keywords: ultrasound; Monument to Ramos de Azevedo; Itaquera Granite.

\section{Resumo}

O presente artigo apresenta os resultados da análise do estado de conservação do Monumento a Ramos de Azevedo por meio do estudo da velocidade de propagação das ondas ultrassônicas. O Monumento a Ramos de Azevedo é de grande importância para a história da cidade de São Paulo - Brasil, pois homenageia o arquiteto de mesmo nome, que foi peça fundamental para o desenvolvimento arquitetônico $e$, consequentemente, social da cidade de São Paulo, que se encontrava estagnada. A obra foi construída em Granito Itaquera, que possui alta dureza, pequena permeabilidade e leve orientação mineral, devido a processos deformacionais. É denominado, petrograficamente, como um biotita monzogranito. O equipamento utilizado foi o V-Meter Mark III com transdutores de $54 \mathrm{kHz}$. Foram realizadas diversas medidas no monumento e as mesmas foram comparadas com os resultados encontrados em rocha fresca. Observando os resultados, concluiu-se que a parte rochosa da base do monumento encontra-se em ótimas condições, mesmo após os dois transportes pelos quais ele passou, pois os valores encontrados são muito próximos dos da rocha fresca. Os valores baixos encontrados foram atribuidos a descontinuidades internas ou a enclaves biotíticos, muito comuns nessa rocha.

Palavras-chave: ultrassom; Monumento a Ramos de Azevedo; Granito Itaquera. 


\section{Introduction}

This paper presents the assessment, by ultrasound technique, of the conservation work done on the Monument to Ramos de Azevedo.

The 25-meter-high Monument to Ramos de Azevedo is located at the University of São Paulo Campus, in the city of São Paulo (Figure 1). The base is made of Itaquera Granite and the sculptures are made of bronze. This monument was inaugurated

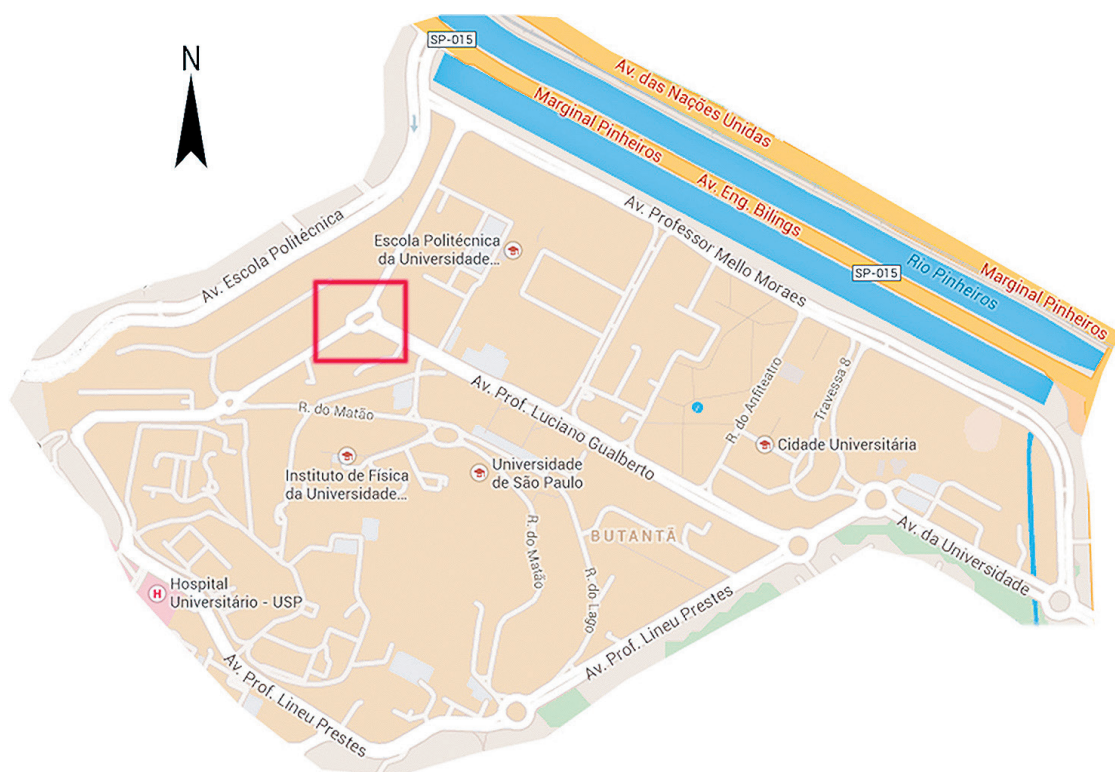

\section{Itaquera Granite}

This granite was widely used in the early 20th century and it is found in several monuments of the city of São

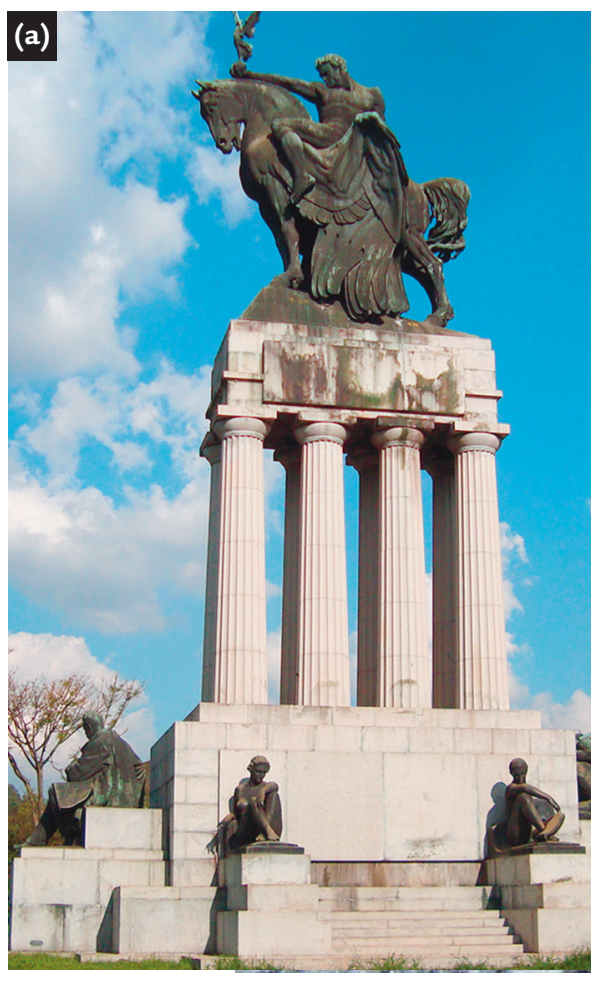

in 1934 on Tiradentes Avenue as a tribute to the architect Ramos de Azevedo. In 1967, it was removed from this site to enlarge the avenue and remained dismantled for years in the Luz Park. In 1975, it was reassembled at the University of São Paulo Campus, where it remains until today.

The importance of using nondestructive methods for the evaluation and monitoring of stone works is

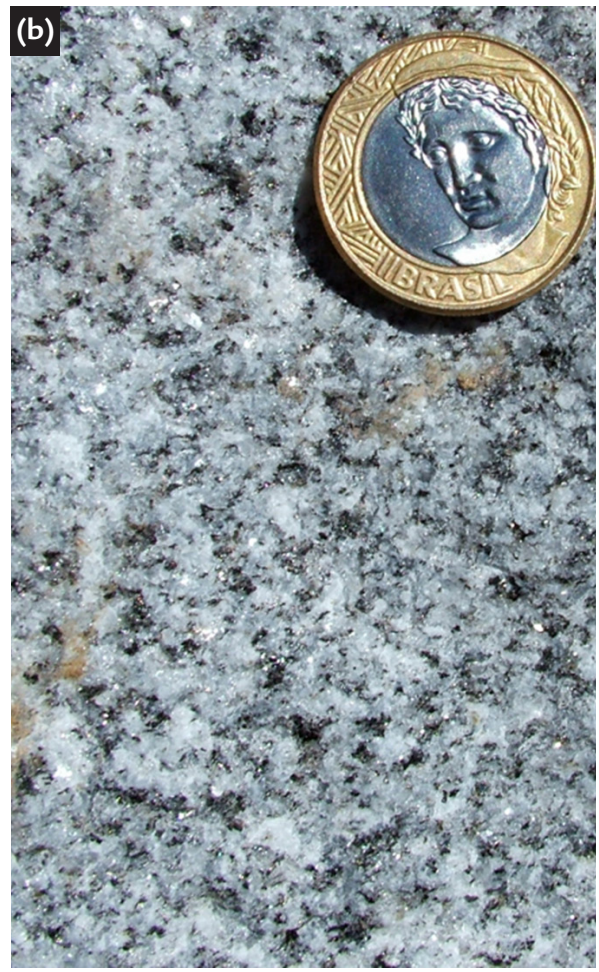

Paulo, including: in the base of The Girl and the Calf, Aretuza, Faun, After the Bath, Nostalgia, The Catcher, in part due to the impossibility of sampling, which would lead to loss of aesthetic value. Ultrasound, jointly with other non-destructive methods, has proven very effective in the evaluation of the physical and mechanical characteristics of stone monuments. Other studies using non-destructive techniques have been performed on this monument (Grossi and Del Lama, 2012; Grossi, 2013).

Figure 1

Location of the monument at Ramos de Azevedo Square (in red) on the University of São Paulo Campus. The longest face is oriented NE-SW.

Source: Google Maps modified.

of St. Benedict Church, in the base of the Municipal Theatre of São Paulo, in the entrance portico of the Consolation

$$
\text { the entrance portico of the Consolation }
$$

\section{Figure 2}

(a) Monument to Ramos de Azevedo, Face NW,

(b) Itaquera Granite in detail. 
Cemetery and in the Monument to Ramos de Azevedo (Figure 2a). Gradually, the use of this stone decreased and it was replaced by Mauá Grey Granite (Del Lama et al., 2009). It is unknown why this substitution occurred, but the probable cause is the better performance of Maua and the depletion of the Itaquera Quarry in 1999. In fact, this quarry hasn't been extracting blocks for ornamental stones and parallelepipeds for years and in the last years it has produced only crushed stone.

\section{Ultrasound pulse velocity method}

The use of ultrasound as a tool to evaluate monuments is of great importance, especially considering objects with small size, from which any kind of material removed will adversely modify the appearance of the work, or considering works protected by law where the removal of material is not allowed. The technique of measuring the P-wave velocities is widely used in Europe where studies are more advanced and the field of conservation has great encouragement.

One way to evaluate the stone degradation in historic buildings and monuments of artistic or cultural value is by using the ultrasound. For this, it is necessary to compare the values of the analyzed stone with the values of the fresh stone (Valdeón et al., 1992). Ultrasonic tests are ideal for quantifying damage in stones, especially if combined with other data (Myrin and Malaga, 2008).

The values of the P-wave velocities

\section{Methodology}

The equipment used in this research was the V-Meter Mark III (NDT James Instruments Inc.) equipped with a digital display that shows the time of propagation, the velocity and amplitude of the wave. The distance between the transducers can be inserted, so the device calculates the velocity or it may be calculated manually using the value of the transit time provided by the device.

Before starting the measurements, it is necessary to calibrate the device and eliminate the travel time of the wave within the transducer (dwell time). The calibration mode varies depending on the equipment.

Only P waves were used, which
The petrographic analysis of Itaquera Granite is found in Del Lama et al. (2009). It has gray color, serial inequigranular granulation, and crystals ranging from 0.2 to $2 \mathrm{~mm}$ (Figure 2b). Locally, centimetric crystals of potassium feldspar occur. The granite has low anisotropy due to its slightly oriented structure. It is called biotite monzogranite and its composition is: oligoclase $(38 \%)$, microcline $(33 \%)$ quartz $(18 \%)$ and biotite $(9 \%)$. Titanite $(1 \%)$ is an accessory mineral; zircon,

are dependent on the stone's physical characteristics such as homogeneity, density, porosity and water saturation, and these factors should be considered in the evaluation of the result of an ultrasonic measurement. The decrease in ultrasonic velocity comes from discontinuities or obstacles in the way of its propagation (Papida et al., 2000; Kahraman, 2002). Mineralogical aspects can also change the P-wave velocities. Another factor that is of great importance is the perfect coupling between the transducers and the surface to be analyzed. If it does not occur, the presence of air between the transducer and the surface can be possible, which will mitigate the result.

The small defects in the stones, on the order of millimeters, can be detected at higher frequencies, preferably above $500 \mathrm{kHz}$. This method can be used to verify the physical behavior of the stone apatite and opaque are found as trace elements; and epidote and fluorite are found as secondary minerals. Micaceous enclaves with centimeter dimensions are common.

Its mineralogy demonstrates a deformation process, indicated by undulatory extinction and recrystallization of the quartz, curved twinning lamellae of the plagioclase and curved biotite crystals. Relative abundance of epidote and saussuritization of the plagioclase are due to hydrothermal alteration.

when it is treated with acids or consolidants (Myrin and Malaga, 2008).

Together with the ultrasound test, two other techniques that can be performed in the field are important for the physical evaluation of the stone, namely: visual analysis of the material and the permeability test. In the laboratory, the ultrasound equipment is easy to use due to the performance at optimal conditions (Myrin and Malaga, 2008).

In Brazil, Marques et al. (2010) determined the geomechanical properties of three gneisses used in a historical heritage in the city of Rio de Janeiro. One method used was to determine the P-wave velocities. The values found, varied according to the strike of the stone foliation and the degree of alteration.

Gimenez and Del Lama (2014) discussed the use of ultrasound procedures in historical monuments. are the most adequate to reflect the internal state of the material.

The smoothest and most accessible stone blocks were chosen on all four sides of the monument. In general, the surfaces are rough due to the bush-hammered finish existing in the stone, which is more pronounced in some points. For the measurements, the $54 \mathrm{kHz}$ transducer, which has 5 $\mathrm{cm}$ in diameter, was used. The direct method was not viable due to the metric dimensions of the monument, making the distance between the opposed faces too big. Thus, the semi-direct method was used.

The measurements were repeated three times at each point and the most constant value or the average value was used. These measurements were made every $10 \mathrm{~cm}$, considering the center of the receiver and transmitter of the transducers, keeping the distance of $10 \mathrm{~cm}$ from the edge of the block. With the aid of a caliper and a ruler the distances between the transducers were obtained. The measurements were performed from left to right, where the right is the body of the monument and the left is its edge. The biggest distance between the transducers which allowed a semidirect method reading was $50 \mathrm{~cm}$.

Laboratory tests on fresh stone with the direct and semi-direct methods were also performed. 


\section{Results}

All the collected data were analyzed as to their value and their stability.

Figure 3 shows the location of the tests on all four sides of the monument and Table 1 points out these results. The coefficient of variation and the standard deviation showed low values with low dispersion of the data.
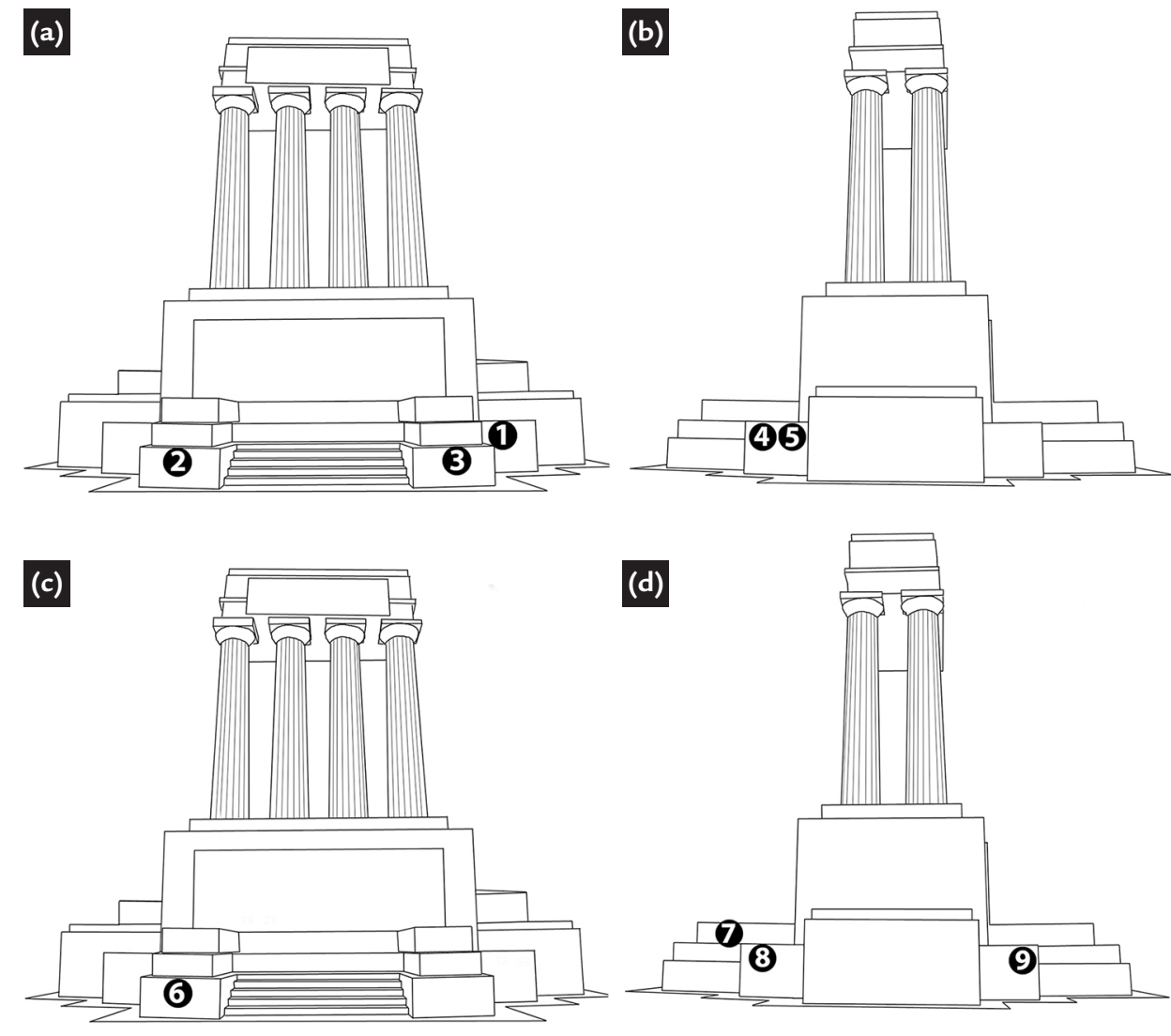

\begin{tabular}{c|c|c|c|c} 
Face & Test & Average $(\mathrm{km} / \mathrm{s})$ & $\begin{array}{c}\text { Standard Devia- } \\
\text { tion }(\mathrm{km} / \mathrm{s})\end{array}$ & $\begin{array}{c}\text { Coefficient of } \\
\text { Variation }(\%)\end{array}$ \\
\hline $\mathrm{SE}$ & 1 & 4.6 & 0.27 & 0.06 \\
\hline $\mathrm{SE}$ & 2 & 4.8 & 0.12 & 0.02 \\
\hline $\mathrm{SE}$ & 3 & 5.2 & 0.12 & 0.02 \\
\hline $\mathrm{NE}$ & 4 & 4.5 & 0.13 & 0.03 \\
\hline $\mathrm{NE}$ & 5 & 4.4 & 0.11 & 0.03 \\
\hline NW & 6 & 5.0 & 0.09 & 0.02 \\
\hline SW & 7 & 4.2 & 0.30 & 0.07 \\
\hline SW & 8 & 4.8 & 0.13 & 0.03 \\
\hline SW & 9 & 4.2 & 0.18 & 0.04 \\
\hline Fresh direct & Block 1 & 4.2 & 0.20 & 0.05 \\
\hline Fresh direct & Block 2 & 4.4 & 0.14 & 0.03 \\
\hline Fresh semi-direct & Block 1 & 4.6 & 0.42 & 0.09 \\
\hline Fresh semi-direct & Block 2 & 4.8 & 0.23 & 0.05 \\
\hline
\end{tabular}

In Figure $4 \mathrm{a}$, it can be seen that the values in the three tests on Face SE with the semi-direct method are very close and four of the values even overlap in tests 1 and 2, showing that there is great uniformity among the different tests on this face. In general, the values vary between 4.1 and $5.4 \mathrm{~km} / \mathrm{s}$.

On Face NE (Figure 4b), the results were quite homogeneous. The velocity ranged from 4.2 to $4.7 \mathrm{~km} / \mathrm{s}$.

The results for Face NW (Figure $4 c)$ showed very little variation, from 4.9 to $5.1 \mathrm{~km} / \mathrm{s}$.

On Face SW (Figure 4d), the results are very similar, with some of them overlapping and ranging from 3.9 to $5.0 \mathrm{~km} / \mathrm{s}$.
Figure 3

Test location:
(a) Face SE,
(b) Face NE,
(c) Face NW,
(d) Face SW.

Table 1

Velocity of propagation of ultrasonic waves with $54 \mathrm{kHz}$ transducers. 
Figure 4

Results obtained by the semi-direct method using $54 \mathrm{kHz}$ transducers on Faces SE (a), NE (b), NW (c) and SW (d).

The fresh stone analyses performed in the laboratory were conducted with direct and semi-direct methods. In the direct method, the values were very constant ranging

Figure 5

Results in fresh Itaquera Granite using $54 \mathrm{kHz}$ transducers with the direct method (a) and semi-direct method (b).

Kuzmickas (2013) used ultrasound to evaluate some tombstones in the Consolation Cemetery in São Paulo. In one of them, the statue Interrogação (Interrogation), made of Itaquera Granite, was analyzed.

\section{Conclusions}

In the series of tests performed at the Monument to Ramos de Azevedo, there is little variation in the results obtained with ultrasound equipment on the same face when various blocks were tested. This observation is due to physical characteristics of the block extraction and transportation conditions, considering that this monument was moved twice after its inauguration on Tiradentes Avenue. Due to the blocks movement, the original installation was lost, preventing the possibility to relate the state of degradation of the stone, based on
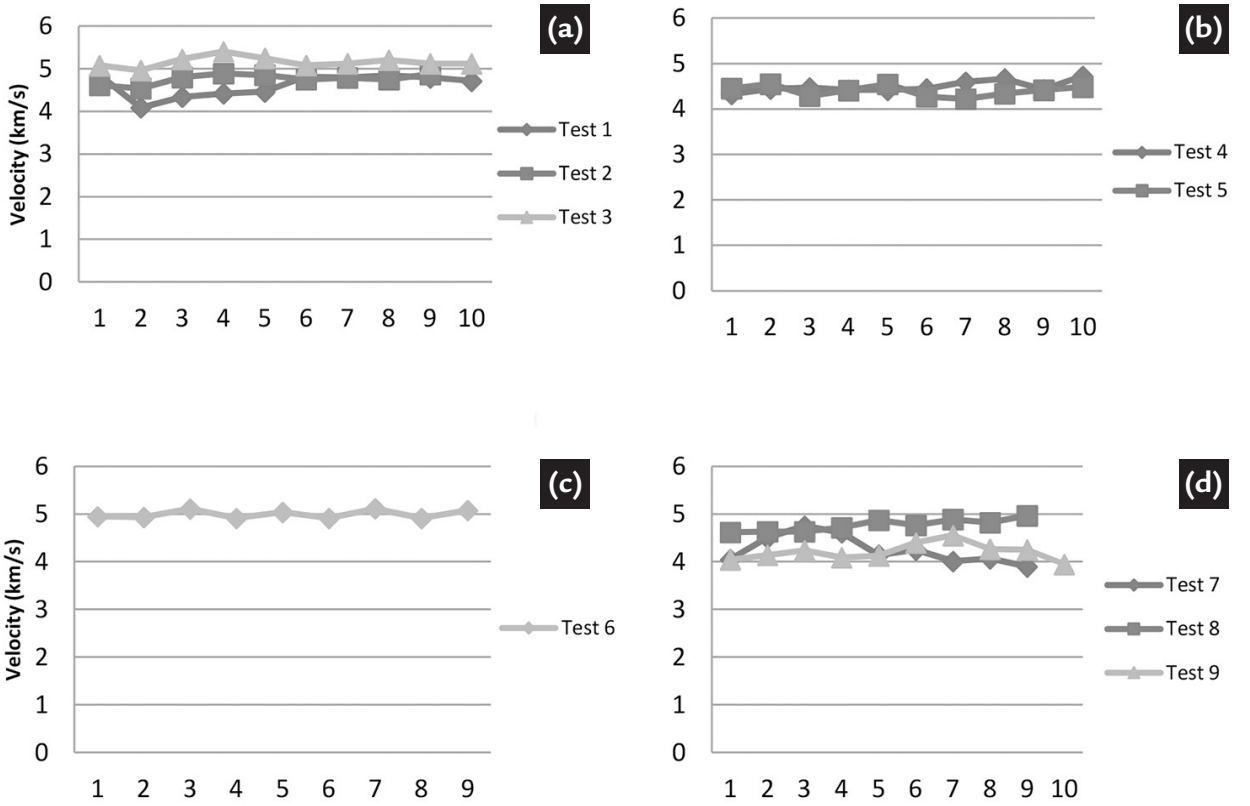

between 3.9 and $4.7 \mathrm{~km} / \mathrm{s}$ (Figure 5a). With the semi-direct method there was a peak value in block 1 . Values ranged from 4.1 to $4.7 \mathrm{~km} / \mathrm{s}$ (Figure 5b), excluding the peak value

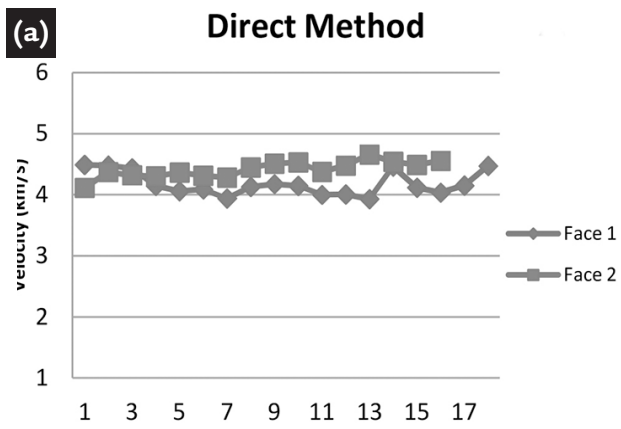

An average velocity of $4.6 \mathrm{~km} / \mathrm{s}$ for the semi-direct method with $54 \mathrm{kHz}$ transducers was found.

Comparing the velocities found in Monument to Ramos de Azevedo with the statue Interrogação, it appears

the velocity of ultrasonic waves, with solar radiation and direction of rains and winds that they received.

The average P-wave velocity with the $54 \mathrm{kHz}$ transducer using the semidirect method on the monument is $4.6 \mathrm{~km} / \mathrm{s}$. Some results showed lower velocities and are not consistent with the condition of the tested surface. This fact was attributed to the possible presence of internal discontinuities.

This velocity was also found in other monuments constituted of Itaquera Granite, as the statue Interrogação (Kuzmickas, 2013). of $6 \mathrm{~km} / \mathrm{s}$. The values found with the semi-direct method were slightly higher than those found with the direct method; a result opposite to what was expected.

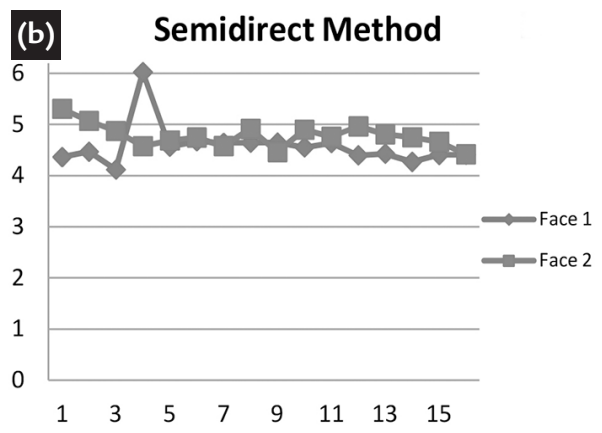

that the two monuments are in similar conditions, which is very close to the condition found in tested fresh blocks, showing that the years of exposure did not affect much the original cohesion of the Itaquera Granite.

For the fresh sample, the average value obtained with the $54 \mathrm{kHz}$ transducer in the semi-direct method is $4.7 \mathrm{~km} / \mathrm{s}$. With the direct method, the average is $4.3 \mathrm{~km} / \mathrm{s}$.

Comparing the values found on the fresh samples and on the monument, it is concluded that the monument is in good conservation state.

The results obtained here attest to the applicability of the ultrasound technique to assess the conservation state of the stone. 


\section{Acknowledgment}

To FAPESP (State of São Paulo Research Foundation) for the grant of the master's scholarship (Proc. n.

2011/03728-0) and research project
(Proc. n. 2009/02519-8).

\section{References}

DEL LAMA, E. A. et alii. Visão geológica dos monumentos da cidade de São Paulo. Revista Brasileira de Geociências, v. 39, n. 3, p. 409-419, 2009.

GIMENEZ, A. M. S., DEL LAMA, E. A. Comportamento de ondas ultrassônicas no Granito Mauá para a conservação do Monumento às Bandeiras. Geologia USP - Revista do Instituto de Geociências USP, v. 14, n. 3, p. 47-60, 2014. (Série Científica).

GROSSI, D. Análise do estado de conservação do Monumento a Ramos de Azevedo com utilização de métodos não destrutivos. São Paulo: Instituto de Geociências, Universidade de São Paulo, 2013. 138 p. (Dissertação de Mestrado).

GROSSI, D., DEL LAMA, E. A. Mapeamento das formas de intemperismo do Monumento a Ramos de Azevedo. Revista CPC, n. 14, p. 169-187, 2012.

KAHRAMAN, S. The effects of fracture roughness on P-wave velocity. Engineering Geology, v. 63, p. 347-350, 2002.

KUZMICKAS, L. Estado de conservação dos monumentos pétreos do Cemitério da Consolação, São Paulo. São Paulo: Instituto de Geociências, Universidade de São Paulo, 2013. 149 p. (Dissertação de Mestrado).

MARQUES, E. A. G. et al. Weathering zones on metamorphic rocks from Rio de Janeiro - Physical, mineralogical and geomechanical characterization. Engineering Geology, v. 111, p. 1-18, 2010.

MYRIN, M., MALAGA, K. Evaluation of consolidation treatment of sandstone by use of ultrasound pulse velocity. In: INTERNATIONAL CONGRESS ON DETERIORATION AND CONSERVATION OF STONE, 11, 2008. Torun (Polônia). Proceedings... Torun: 2008. v. 1, p. 441-448.

PAPIDA, S. et alii. The use of sound velocity determination for the non-destructive estimation of physical and microbial weathering of limestones and dolomites. In: INTERNATIONAL CONGRESS ON DETERIORATION AND CONSERVATION OF STONE, 9, 2000. Venice (Itália). Proceedings... Venice: Elsevier, 2000. v. 1, p. 609-617.

VALDEÓN, L. et alii. Ultrassonic methods for quantifying the degradation of building stones. In: INTERNATIONAL CONGRESS ON DETERIORATION AND CONSERVATION OF STONE, 7, 1992. Lisbon (Portugal). Proceedings... Lisbon: Laboratório Nacional de Engenharia Civil, 1992. v. 2, p. 697-704.

Received: 07 May 2014 - Accepted: 13 April 2015. 